\title{
The psychological profile of parents who volunteer their children for clinical research: a controlled study
}

\author{
S C Harth, R R Johnstone and Y H Thong University of Queensland
}

\section{Authors' abstract}

Three standard psychometric tests were administered to parents who volunteered their children for a randomised, double-blind placebo-controlled trial of a new asthma drug and to a control group of parents whose children were eligible for the trial but had declined the invitation. The trial took place at a children's hospital in Australia. The subjects comprised 68 parents who had volunteered their children and 42 who had not, a participation rate of 94 per cent and 70 per cent, respectively. The responses of these parents to the Gordon Survey of Interpersonal Values Questionnaire, the Coopersmith Self-Esteem Inventory and the Cattell Sixteen Personality Factor Questionnaire were analysed by computer. There was a marked difference between the psychological profiles of the two groups of parents. Volunteering parents put more value on benevolence while non-volunteering parents were more concerned with power and prestige. The self-esteem of volunteering parents was much lower than that of nonvolunteering parents. Finally, volunteering parents were more introverted, exhibited greater anxiety and low supergo, while non-volunteering parents appeared to have greater social confidence and emotional stability. Since an individual's values, self-esteem and personality may be important antecedents of behaviour, these findings suggest that parents who volunteer their children for clinical research are not only socially disadvantaged and emotionally vulnerable, but may also be psychologically predisposed to volunteering. Furthermore, these findings provide evidence for the existence of a psychosocial 'filter' effect of the informed consent procedure, which may be discouraging the better educated, more privileged and psychologically resilient members of society from participation as research subjects.

\section{Introduction}

The social mandate which governs clinical research permits the exposure of some members of society to calculated risks as research subjects in exchange for the real or potential benefits of medical progress to the community as a whole (1-3). One corollary of this

\section{Key words}

Clinical research; informed consent; proxy consent; minors. mandate is that the burden of participation be equitably spread across all segments of society $(4,5)$. Another corollary is that additional safeguards be accorded to vulnerable members of society, such as children, prisoners, students and the mentally retarded, so that they are usually exempt from participation in non-therapeutic research, and from research with more than minimal risks.

We had the opportunity to examine these issues while conducting a randomised controlled trial of a new asthma drug in children (6). We found that volunteering parents were more socially disadvantaged than non-volunteering parents. Also, volunteering parents were more vulnerable in terms of their behavioural characteristics than non-volunteering parents. Because of the nexus between psychology and behaviour, we further subjected these two groups of parents to psychometric testing with three standard personality and behavioural assessments in order to obtain a comparative description of their psychological profiles.

\section{Subjects and methods}

The volunteer subjects recruited for this study were parents who volunteered their children for a randomised, double-blind placebo-controlled trial of a new and as yet unlicensed (for Australia) oral antiasthma drug (ketotifen) (6). As is usual with such therapeutic trials, there were strict inclusion and exclusion criteria. The children were between the ages of six months and three years, and had symptoms of cough and wheeze on at least 50 per cent of days in the three-month period preceding commencement of the trial and continued to show symptoms for the onemonth assessment period before starting medication. These children were not receiving corticosteroids or cromoglycate and were not responding well to the bronchodilators salbutamol and theophylline. It was thought that ketotifen might have a role in the interval management of these children. Altogether, 68 families from the volunteer group agreed to participate in personality studies, which was $\mathbf{9 4 . 5}$ per cent of those approached. The non-volunteers (comparison group) were recruited from parents who were invited to allow their eligible children to participate in the therapeutic trial for asthma, but who refused after due 
consideration. Altogether, 42 families from the nonvolunteer group, which was 70.0 per cent of those approached, agreed to co-operate for the personality study. An interview was conducted to determine which parent had made the major part of the decision either to allow or refuse their child's participation in the clinical trial and this parent was invited to undergo psychometric assessments. The volunteer group consisted of 52 ( 76.5 per cent $)$ mothers and 16 (23.5 per cent) fathers, while gender of the respondents in the non-volunteer group was evenly distributed, with 21 ( 50.0 per cent) mothers and 21 ( 50.0 per cent) fathers. Subjects were advised that the objective of the study was to determine if there were any major differences in the personalities of volunteer and non-volunteer parents. An informed consent form was signed by each participant. The study was approved by the Mater hospital ethics committee.

We selected three standard personality and behavioural assessments for psychometric testing of the 68 volunteering and 42 non-volunteering parents. Their values and temperament were measured with the Gordon Survey of Interpersonal Values Questionnaire (7) which comprises 30 sets of three statements, representing 12 different value dimensions. Their selfesteem was evaluated with the Coopersmith SelfEsteem Inventory (8) which consists of 20 questions on a two-point scale. Their personalities were assessed with Form C of the Cattell Sixteen Personality Factor Questionnaire (16PF) $(9,10)$, which consists of 105 items on a three-point scale. The forced-choice format was employed throughout and the tests were administered under strict standard conditions. The data were converted to standard scores and analysed by computer using the SAS statistical package (11). The Student's t-test was used for statistical analysis.

\section{Results \\ INTERPERSONAL VALUES}

The results of the Gordon Survey of Interpersonal Values Questionnaire are summarised in Table I. Of the six values surveyed there were no statistically significant differences between the two groups of parents in the values of Support, Conformity and Independence. However, volunteering parents scored significantly higher on the value of Benevolence, and significantly lower on the values of Recognition and Leadership.

SELF-ESTEEM

Volunteering parents were found to have significantly lower mean self-esteem scores than non-volunteering parents on the Coopersmith Self-Esteem Inventory $(61.1 \pm 4.7$ v $90.7 \pm 6.9, \mathrm{t}=8.86, \mathrm{df}=108, \mathrm{p}<0.001)$.

PERSONALITY PROFILE

The results of the Cattell 16PF Questionnaire are presented in Table II. Also shown are the letter symbols for each factor, the psychological terminology for each factor, and the bi-polar description of each trait. Standardised sten scores are distributed over ten

\section{Table I Interpersonal values of volunteering and non-volunteering parents as assessed by the Gordon Survey of Interpersonal Values}

\begin{tabular}{|c|c|c|c|c|c|c|}
\hline & $\begin{array}{l}\text { Interpersonal } \\
\text { Values }\end{array}$ & $\begin{array}{c}\text { Score }(\mathbf{m} \\
\text { Volunteering } \\
\text { parents }(n=68) \\
\text { mean } \pm \text { SD }\end{array}$ & $\begin{array}{l}\text { ean } \% \text { SD) } \\
\text { Non-volunteering } \\
\text { Parents }(n=42) \\
\text { mean } \pm \text { SD }\end{array}$ & t value & df & p value \\
\hline 1 & $\begin{array}{l}\text { SUPPORT (Being treated with understanding, } \\
\text { receiving encouragement from other people, } \\
\text { being treated with kindness and consideration) }\end{array}$ & $58.5 \pm 26.2$ & $49.3 \pm 31.2$ & 1.66 & 108 & 0.099 \\
\hline 2 & $\begin{array}{l}\text { CONFORMITY (Doing what is socially correct, } \\
\text { following regulations closely, doing what is } \\
\text { accepted and proper, being a conformist) }\end{array}$ & $37.2 \pm 25.4$ & $28.6 \pm 25.6$ & 1.72 & 108 & 0.088 \\
\hline 3 & $\begin{array}{l}\text { RECOGNITION (Being looked up to and admired, } \\
\text { being considered important, attracting } \\
\text { favourable notice, achieving recognition) }\end{array}$ & $46.1 \pm 27.4$ & $60.5 \pm 27.5$ & 2.67 & 108 & 0.009 \\
\hline 4 & $\begin{array}{l}\text { INDEPENDENCE (Having the right to do whatever } \\
\text { one wants to do, being able to do things in } \\
\text { one's own way) }\end{array}$ & $62.6 \pm 31.2$ & $57.7 \pm 25.0$ & 0.86 & 108 & 0.391 \\
\hline 5 & $\begin{array}{l}\text { BENEVOLENCE (Doing things for other people, } \\
\text { sharing with others, helping the unfortunate, } \\
\text { being generous) }\end{array}$ & $54.0 \pm 29.7$ & $25.2 \pm 25.0$ & 5.24 & 108 & $<0.001$ \\
\hline 6 & $\begin{array}{l}\text { LEADERSHIP (Being in charge of other people, } \\
\text { having authority over others, being in a } \\
\text { position of leadership or power) }\end{array}$ & $38.2 \pm 23.7$ & $80.0 \pm 25.7$ & 8.70 & 108 & $<0.001$ \\
\hline
\end{tabular}


Table II Personality traits of volunteering and non-volunteering parents as asessed by the Cattell Sixteen Personality Factor (16PF) Test Profile

\begin{tabular}{|c|c|c|c|c|c|c|c|}
\hline \multirow{2}{*}{$\begin{array}{c}\begin{array}{c}\text { Personality } \\
\text { Factor }\end{array} \\
\text { A }\end{array}$} & \multicolumn{2}{|c|}{$\begin{array}{c}\text { BIPOLAR DESCRIPTION OF SOURCE TRAITS } \\
\text { Low Sten Store } \\
\text { High Sten Score } \\
(1-3)\end{array}$} & \multicolumn{2}{|c|}{\begin{tabular}{cc|}
\multicolumn{2}{|c|}{ Score $($ mean $\pm S D)$} \\
Volunteering & Non-volunteering \\
parents $(n=68)$ & Parents $(n=42)$
\end{tabular}} & t value & df & p value \\
\hline & $\begin{array}{l}\text { SIZOTHYMIA } \\
\text { (Reserved, detached, } \\
\text { critical, impersonal) }\end{array}$ & $\begin{array}{l}\text { AFFECTOTHYMIA } \\
\text { (Warmhearted, outgoing, } \\
\text { participating) }\end{array}$ & $3.3 \pm 1.7$ & $5.5 \pm 1.7$ & 6.59 & 108 & $<0.001$ \\
\hline B & $\begin{array}{l}\text { LOW MENTALCAPACITY } \\
\text { (Less intelligent, } \\
\text { concrete-thinker) }\end{array}$ & $\begin{array}{l}\text { HIGHER MENTALCAPACITY } \\
\text { (More intelligent, } \\
\text { bright, abstract-thinker }\end{array}$ & $6.8 \pm 1.6$ & $8.5 \pm 1.2$ & 5.93 & 108 & $<0.001$ \\
\hline $\mathrm{C}$ & $\begin{array}{l}\text { LOWER EGOSTRENGTH } \\
\text { (Affected by feelings, easily } \\
\text { upset, less stable emotionally }\end{array}$ & $\begin{array}{l}\text { HIGHER EGOSTRENGTH } \\
\text { (Emotionally stable, } \\
\text { mature, faces reality) }\end{array}$ & $4.7 \pm 2.2$ & $7.1 \pm 1.8$ & 5.94 & 108 & $<0.001$ \\
\hline E & $\begin{array}{l}\text { SUBMISSIVENESS } \\
\text { (Humble, mild, easily led, } \\
\text { conforming, accommodating }\end{array}$ & $\begin{array}{l}\text { DOMINANCE } \\
\text { (Assertive, aggressive, } \\
\text { competitive, authoritative) }\end{array}$ & $7.2 \pm 2.4$ & $6.2 \pm 2.1$ & 2.22 & 108 & $<0.028$ \\
\hline F & $\begin{array}{l}\text { DESURGENCY } \\
\text { (Sober, prudent, } \\
\text { serious, taciturn) }\end{array}$ & $\begin{array}{l}\text { SURGENCY } \\
\text { (Happy-go-lucky, } \\
\text { enthusiastic, heedless) }\end{array}$ & $4.8 \pm 1.8$ & $6.7 \pm 1.7$ & 5.49 & 108 & $<0.001$ \\
\hline G & $\begin{array}{l}\text { WEAK SUPEREGOSTRENGTH } \\
\text { (Expedient, disregards rules, } \\
\text { feels few obligations) }\end{array}$ & $\begin{array}{l}\text { STRONG SUPEREGOSTRENGTH } \\
\text { (Conscientious, moralistic, } \\
\text { proper rule-bound) }\end{array}$ & $5.4 \pm 2.5$ & $6.4 \pm 1.7$ & 2.28 & 108 & $<0.024$ \\
\hline $\mathbf{H}$ & $\begin{array}{l}\text { THRECTIA } \\
\text { (Shy, restrained, timid, } \\
\text { threat-sensitive) }\end{array}$ & $\begin{array}{l}\text { PARMIA } \\
\text { (Venturesome, } \\
\text { uninhibited, socially bold ) }\end{array}$ & $3.8 \pm 2.2$ & $7.2 \pm 2.1$ & 8.01 & 108 & $<0.001$ \\
\hline I & $\begin{array}{l}\text { HARRIA } \\
\text { (Touch-minded, realistic, } \\
\text { self-reliant) }\end{array}$ & $\begin{array}{l}\text { PREMSIA } \\
\text { (Tender-minded, unrealistic, } \\
\text { sensitive) }\end{array}$ & $5.0 \pm 2.3$ & $5.8 \pm 1.8$ & 1.92 & 108 & $<0.058$ \\
\hline L & $\begin{array}{l}\text { ALAXIA } \\
\text { (Trusting, adaptable, } \\
\text { easy to get on with) }\end{array}$ & $\begin{array}{l}\text { PROTENSION } \\
\text { (Suspicious, self- } \\
\text { opinionated, skeptical) }\end{array}$ & $7.8 \pm 1.9$ & $6.8 \pm 2.5$ & 2.37 & 108 & $<0.019$ \\
\hline$M$ & $\begin{array}{l}\text { PRAXERNIA } \\
\text { (Practical, careful, } \\
\text { conventional) }\end{array}$ & $\begin{array}{l}\text { AUTIA } \\
\text { (Imaginative minded, } \\
\text { bohemian) }\end{array}$ & $5.9 \pm 2.4$ & $6.1 \pm 1.8$ & 0.46 & 108 & $<0.643$ \\
\hline $\mathrm{N}$ & $\begin{array}{l}\text { NAÏVETÉ } \\
\text { (Forthright, natural, } \\
\text { genuine) }\end{array}$ & $\begin{array}{l}\text { SHREWDNESS } \\
\text { (Shrewd, calculating, } \\
\text { insightful) }\end{array}$ & $6.9 \pm 2.1$ & $5.3 \pm 1.8$ & 4.09 & 108 & $<0.001$ \\
\hline $\mathrm{O}$ & $\begin{array}{l}\text { UNTROUBLED ADEQUACY } \\
\text { (Unperturbed, self-assured, } \\
\text { confident, serene) }\end{array}$ & $\begin{array}{l}\text { GUILT PRONENESS } \\
\text { (Apprehensive, worrying, } \\
\text { troubled) }\end{array}$ & $6.9 \pm 2.1$ & $3.5 \pm 1.5$ & 9.14 & 108 & $<0.001$ \\
\hline Q1 & $\begin{array}{l}\text { CONSERVATIVE } \\
\text { TEMPERAMENT } \\
\text { (Conservative, respecting established } \\
\text { ideas) }\end{array}$ & $\begin{array}{l}\text { RADICALIS } \\
\text { (Experimenting, liberal, } \\
\text { analytical) }\end{array}$ & $7.6 \pm 1.9$ & $8.2 \pm 1.7$ & 1.67 & 108 & $<0.097$ \\
\hline Q2 & $\begin{array}{l}\text { GROUP ADHERENCE } \\
\text { (Group oriented, a "joiner" } \\
\text { and sound follower) }\end{array}$ & $\begin{array}{l}\text { SELF-SLFFICIENCY } \\
\text { (Resourceful, prefers } \\
\text { own decisions) }\end{array}$ & $3.7 \pm 2.3$ & $3.5 \pm 1.9$ & 0.47 & 108 & $<0.638$ \\
\hline Q3 & $\begin{array}{l}\text { LOW INTEGRATION } \\
\text { (Undisciplined self-conflict, } \\
\text { careless of social rules) }\end{array}$ & $\begin{array}{l}\text { ABILITY TO BIND } \\
\text { ANXIETY } \\
\text { (Controlled, socially precise, } \\
\text { following self-image) }\end{array}$ & $5.0 \pm 2.4$ & $7.2 \pm 1.7$ & 5.19 & 108 & $<0.001$ \\
\hline Q4 & $\begin{array}{l}\text { LOW ERGIC TENSION } \\
\text { (Relaxed, tranquil, torpid } \\
\text { unfrustrated) }\end{array}$ & $\begin{array}{l}\text { HIGH ERGIC TENSION } \\
\text { (Tense, frustrated, } \\
\text { restless, over-wrought) }\end{array}$ & $6.3 \pm 2.0$ & $4.0 \pm 1.9$ & 5.97 & 108 & $<0.001$ \\
\hline
\end{tabular}


equal interval score points, with the population mean set at 5.5. There were significant differences between the two groups of parents in 12 of the 16 personality factors. Thus, volunteering parents had significantly higher scores on the factors of Dominance (E), Protension (L), Shrewdness (N), Guilt Proneness (O) and Ergic Tension (Q4). By contrast, non-volunteering parents had significantly higher scores on the personality factors of Affectothymia (A), Mental Capacity (B), Higher Ego Strength (C), Surgency (F), Super Ego Strength (G), Parmia $(\mathrm{H})$ and Ability to Bind Anxiety (Q3).

The Cattell 16PF data were further subjected to second-stratum analysis in order to obtain another perspective on the personality profiles of the two groups of parents. Second-stratum personality factors may be regarded as broader influences or organisers contributing to the primary factors of the $16 \mathrm{PF}$ and may be obtained by correlating the primary factors $(9,10)$. Thus, factors $\mathrm{C}, \mathrm{H}, \mathrm{L}, \mathrm{O}, \mathrm{Q} 3$ and $\mathrm{Q} 4$ are all expressions of Anxiety and a more complete picture may be obtained by computing the score on this second level. A bi-polar title of the five major second-stratum personality factors is listed in Table III, as well as the principal factors from which each second-stratum factor is derived. Because of systematic differences between males and females, the genders were separated for some of the analysis. The results (Table III) show significant differences between the two groups in three or five second-stratum factors. While volunteering parents had significantly higher scores on Anxiety (Factor II), non-volunteering parents had significantly higher scores on Extraversion (Factor I) and Superego (Factor V). The scores for the factors of Toughmindedness (Factor III) and Independence (Factor IV) were not significantly different between the two groups.

A comparison of the second-stratum personality factors of both groups of parents with the population mean using $\mathrm{Z}$-scores of the primary factors is shown in Figure 1. It can be observed that both groups of parents are significantly different from the population mean with regard to the second-stratum personality factors of Extraversion (Factor I), Anxiety (Factor II) and High-Superego (Factor V), and that the profiles of these two groups of parents tend to run in different directions from the population mean for these three second-stratum factors.

Finally, we included the motivational distortion scale of the Cattell 16PF to detect attempts at 'faking good', because the 16PF Questionnaire may be susceptible to distortion and deliberate faking $(9,10)$. The results show that non-volunteering parents had a significantly higher mean ( \pm S.D.) score than volunteering parents $(5.4 \pm 1.8 \times 4.1 \pm 1.8 . \mathrm{t}=3.68$, $\mathrm{df}=108, \mathrm{p}<0.001)$. However, both scores were below 6 , the upper limit of reliability (10). In this scale, a score of 7 or more is regarded as suspicious, while 12 or more (maximum 14) indicates a deliberate attempt to fake (10).

\section{Table III The Cattell 16PF second-stratum personality factors on volunteering and non- volunteering parents}

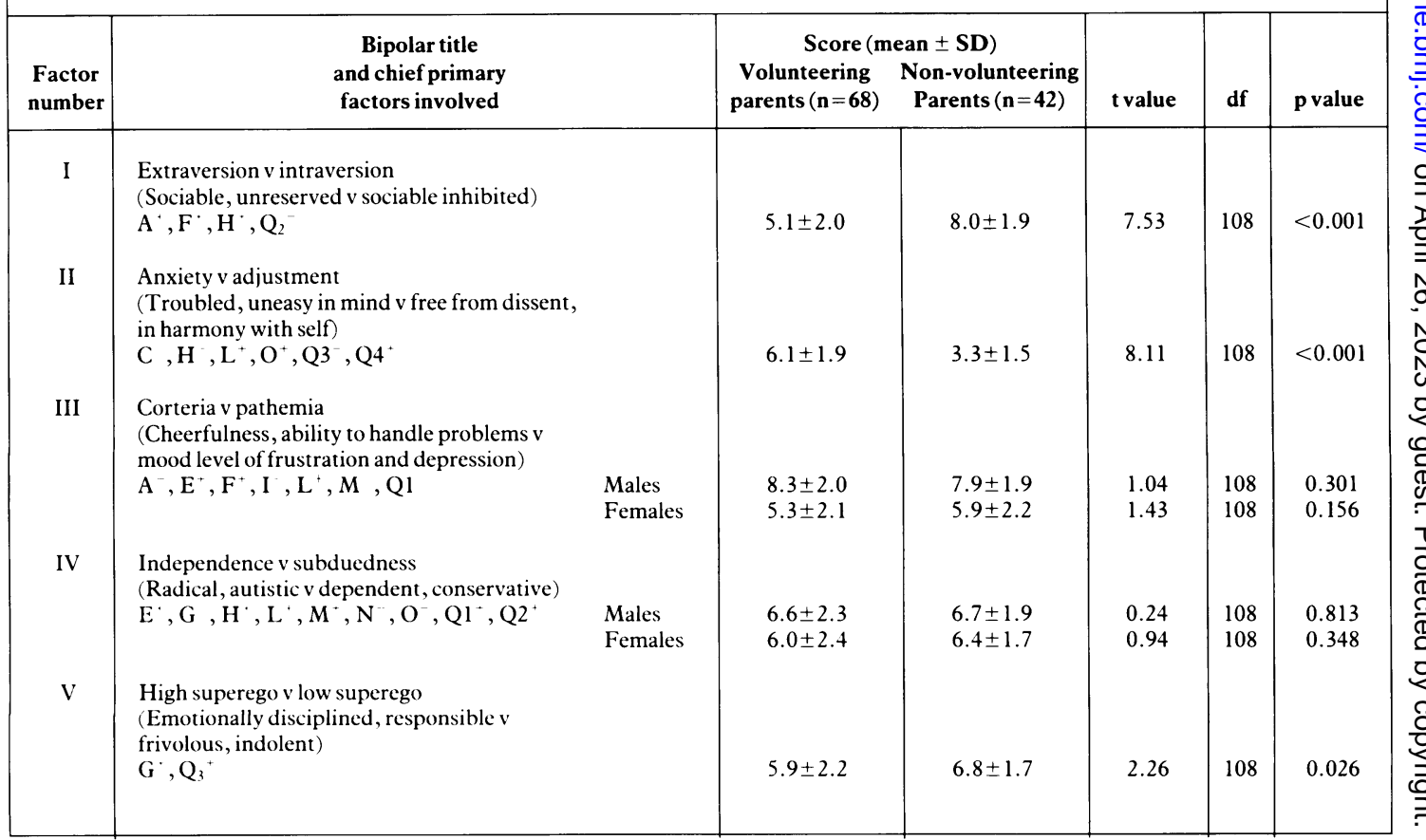




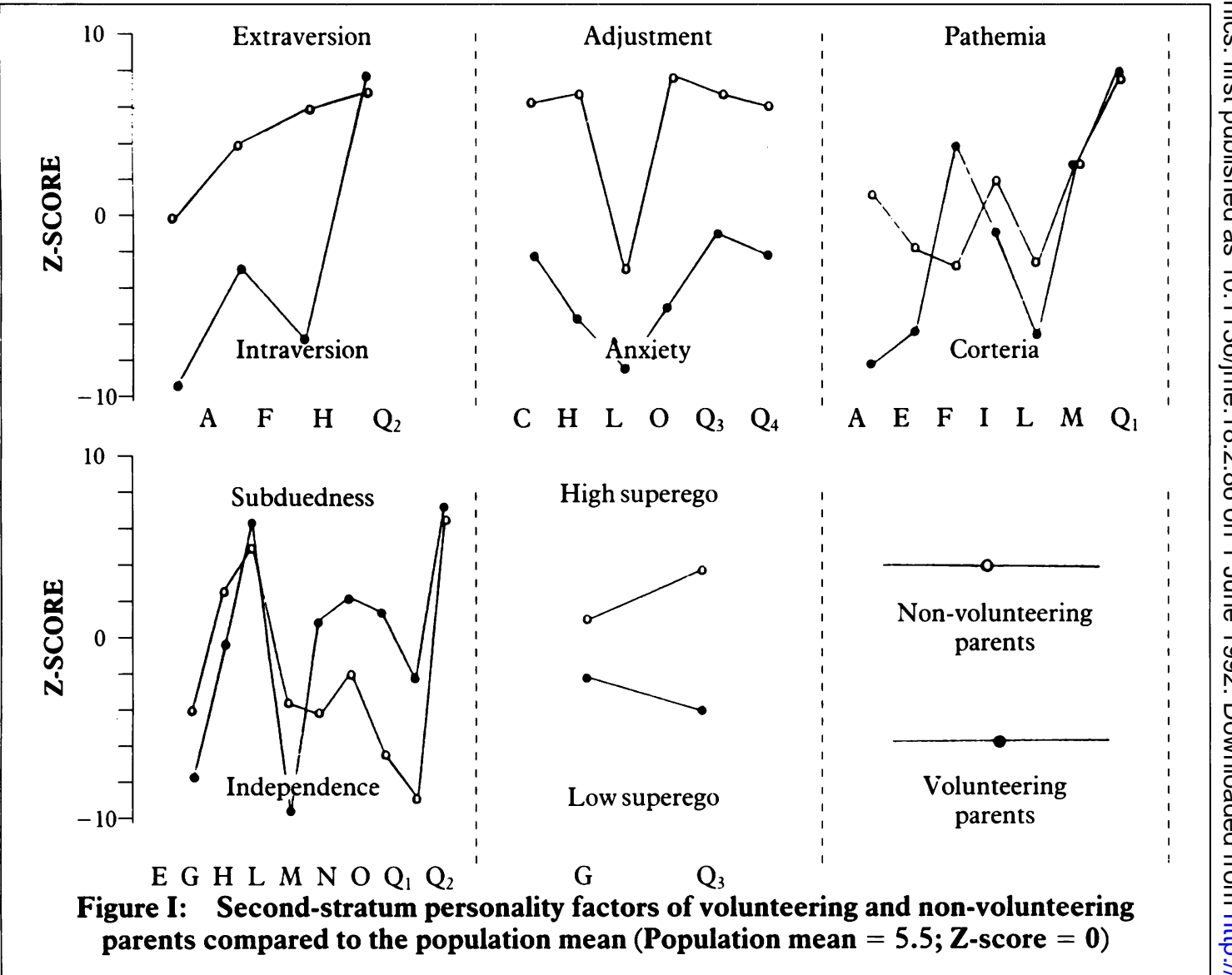

\section{Discussion}

As reported in a previous paper (6), the volunteering and non-volunteering parents were similar to each other in terms of age, birth order, parity and ethnic background. Their children were also concordant for age and severity of illness. However, volunteering parents were significantly less well-educated and less well-represented in professional and managerial occupations. Also, volunteering parents had significantly less social support and displayed greater health-seeking behaviour and used more habitforming substances. As well, volunteering parents appeared to be motivated not only by a need to find better ways to help their children, but also by a desire to help others and contribute to medical research.

This study of their psychological profiles confirms and extends the previous observations. For this study, we selected three standard psychometric assessments regarded as important determinants of behaviour. Thus, a person's values may have critical relevance to the act of volunteering, and in this regard, it was shown that volunteering parents had significantly higher scores on the factor of Benevolence, consistent with their stated desire to help others. Low self-esteem is generally associated with feelings of inadequacy, isolation and worthlessness, and the finding of significantly lower self-esteem in volunteering parents may explain their greater need to seek professional contact and enrol their children in clinical research. The personality profiles of volunteering parents were also significantly different from both the population mean and the non-volunteering parents. Volunteering parents may be described as more assertive, sceptical, shrewd and tense individuals with difficulty in dealing with anxiety, and may be more predisposed to enrolling their children in clinical research as a way of coping with having young children with a distressing illness.

These findings lend some credence to Silverman's conjecture (12) that the informed consent process may act as a social filter to select for inclusion 'those who do not understand, those too frightened to refuse, those who are socially disadvantaged', though perhaps not in such harsh terms. While the volunteering parents were socially disadvantaged, they did not appear too frightened to refuse; rather the act of volunteering appears to be determined not only by their own social circumstances but also in part by their own values and psychological needs. The informed consent process may also have selected out 'for refusal, those on the upper rungs of the social ladder, the least captive 


\section{Worksheet for Figure 1}

Second-stratum personality factors of volunteering and non-volunteering parents compared to the population mean (population mean $=5.5 ; \mathrm{SD}=2.0$ )

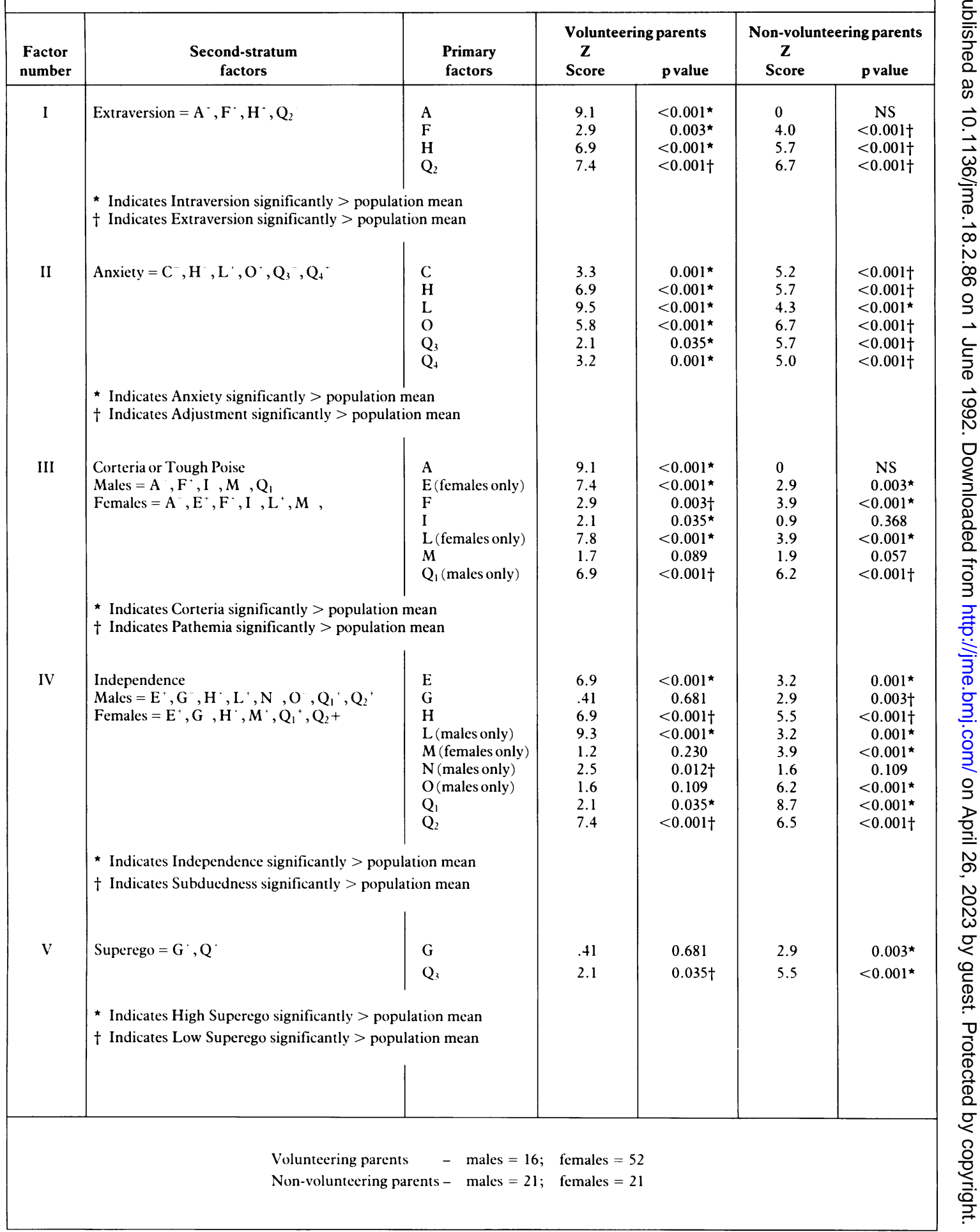


members of the community, those most likely to understand what is requested in the consent ritual', but again the psychological make-up of non-volunteering parents may contribute as much to their decision as their relatively higher standing. In this regard, nonvolunteering parents may be described as being more concerned with power and prestige than with benevolence, having greater self-esteem, and being more intelligent, socially confident and emotionally disciplined.

The sample size is not large, so the data should be interpreted with some degree of caution. As far as we can determine, there was no selection bias in the recruitment of subjects. The participation rate of nonvolunteering parents is only 70 per cent, but this may reflect an inherent aversion to volunteering in this group. The three psychometric tests selected for this study are well-established ones with good reliability. There is also internal consistency in the results; for instance the stated desire of volunteering parents to contribute to medical research correlates well with their value for benevolence, and their low self-esteem correlates well with the second-stratum personality factor of anxiety. Although there is a greater tendency for the non-volunteering parents to 'fake good', their mean motivational distortion score was within the normal range. The only way of reducing this tendency to 'fake good' would be to administer the psychometric tests without informing the parents of the study objectives, but this would be unethical and impractical in the clinical situation. In any event, comparison of the volunteering parents against the population mean confirms the observation of psychological vulnerability in this group.

In conclusion, our findings indicate that parents who volunteer their children for clinical research are not only socially disadvantaged and emotionally vulnerable, but may also be psychologically predisposed to volunteering. These findings have a number of important implications. One is that of social equity, where the problem of over-representation as research subjects by the socially disadvantaged (4-6) is compounded by the social filter effect of the informed consent process $(12,13)$. Another is sampling bias which results from the withdrawal of the more intelligent, psychologically resilient and privileged members of the community, although this may be a more important consideration for sociological and psychological research than for drug trials $(14,15)$. A third implication is that of eligibility of vulnerable groups as research subjects; in this regard, children, prisoners, students and the mentally handicapped are generally exempt, because of their lack of autonomy and inherent inability to provide fully informed consent $(1,2)$. There is no total prohibition of the participation of children in clinical research, because of its importance to the health and well-being of all children, but additional safeguards are imposed, and the issue of proxy consent remains controversial $(16,17)$. In the light of our findings, it may be necessary to take into consideration the vulnerability not only of children, but also of their parents, in the recruitment of child subjects for clinical research.

\section{Authors' note}

For those unfamiliar with statistical analysis, the abbreviations ' $t$ ', ' $d f$ ' and ' $p$ ' used in the tables have the following meaning:

' $t$ ' ia a value obtained from using the student's $t$ test to compare the means of two samples. ' $\mathrm{df}$ ' is the degree of freedom, and in the $t$ test is calculated from the formula $N_{x}+N_{y}-2$, where $N_{x}$ is the size of the first sample and $\mathrm{N}_{\mathrm{y}}$ the size of the second sample. The $\mathrm{p}$ value is a numerical expression of the probability of an event occurring by chance; a p value of less than 5 per cent $(<0.05)$ is considered statistically significant, and the smaller the $p$ value, the greater the statistical significance.

\section{Acknowledgements}

This work was supported in part by a grant from the Mayne Bequest Fund, University of Queensland. We thank Dr M R Dadds, Senior Lecturer, Department of Psychology, University of Queensland, for useful discussions and assistance.

$S C$ Harth, RN, is a Senior Research Assistant in the Department of Child Health, University of Queensland Mater Childrens Hospital. $R R$ fohnstone, $M A$, is a Specialist Tutor in the Department of Psychology, University of Queensland. Y $H$ Thong, FRACP, is Professor of Child Health in the Department of Child Health, University of Queensland Mater Children's Hospital, South Brisbane 4101, Australia.

\section{References}

(1) Levine R J. Ethics and regulation of clinical research. Baltimore: Urban and Schwarzenberg, 1986.

(2) Spicker S F, Alon I, de Vries A, Eggelhardt H T. The use of human beings in research with special reference to clinical trials. Dordrecht: Kluwer Academic, 1988.

(3) Baum M, Zilkha K, Houghton J. Clinical research: lessons for the future. British medical journal 1989; 299 251-253.

(4) Barber B, Lally J J, Makaruschhka J L, Sullivan D. Research on human subjects: problems of social control in medical experimentation. New York: Russell Sage Foundation, 1973.

(5) Cooke R A. Some notes on the subjects of biomedical and behavioural research. Report prepared for the president's commission for the study of ethical problems in medicine and biomedical and behavioural research. Washington DC: United States Government Printing Office, 1980.

(6) Harth S C, Thong Y H. Sociodemographic and motivational characteristics of parents who volunteer their children for clinical research: a controlled study. British medical journal 1990; 300: 1372-1375.

(7) Gordon L V. The measurement of interpersonal values Chicago: Science Research Associates, 1975.

(8) Coopersmith S. Self-esteem inventories. Palo Alto: 
Consulting Psychologists Press, 1981.

(9) Cattell R B, Eber H W, Tatsuoka M M. Handbook for the sixteen personality factor questionnaire. Champaign: Institute for Personality and Ability Testing, 1970.

(10) Karson S, O'Dell J W. Clinical use of the 16PF. Champaign: Institute for Personality and Ability Testing, 1976.

(11) SAS Institute. SAS,SASISTAT. Guide for personal computers (6th ed). Cary, North Carolina: SAS Institute, 1987.

(12) Silverman W A. The myth of informed consent: in daily practice or in clinical trials. Fournal of medical ethics 1989; 299: 251-253.

(13) Thong Y H, Harth S C. Commentary: the social filter effect of informed consent in clinical research. Pediatrics (in press).

(14) Edlund M J, Craig T J, Richardson M A. Informed consent as a form of volunteer bias. American journal of psychiatry 1985; 142: 624-627.

(15) Walterspiel J N. Informed consent: influence on patient selection among critically ill premature neonates. Pediatrics 1990; 85: 118-121.

(16) McCormick R A. Proxy consent in the experimentation situation. Prospectus of biology and medicine 1974; 18: 220.

(17) Van de Veer D. Experimentation on children and proxy consent. Fournal of medicine and philosophy 1981; 6: 281293. 